\title{
KEMAMPUAN BERPIKIR KRITIS PESERTA DIDIK DALAM MENYELESAIKAN MASALAH MATEMATIKA MELALUI MODEL PEMBELAJARAN PROBLEM BASED LEARNING DI KELAS VII SMP NEGERI 1 GLAGAH LAMONGAN
}

\author{
Muhammad Syarif Hidayatullah $^{1}$, Irwani Zawawi ${ }^{2}$, Fatimatul Khikmiyah ${ }^{3}$ \\ Universitas Muhammadiyah Gresik ${ }^{1}$ \\ Email: Hidayatullahsyarif765@yahoo.co.id \\ Universitas Muhammadiyah Gresik ${ }^{2}$ \\ Email: irwanizawawi@umg.ac.id \\ Universitas Muhammadiyah Gresik ${ }^{3}$ \\ Email: fatimatulkhikmiyah@gmail.com
}

\begin{abstract}
Abstrak
Kemampuan berpikir kritis dapat melatih peserta didik membuat keputusan dari berbagai sudut pandang secara cermat, teliti, dan logis. Dengan kemampuan berpikir kritis, peserta didik dapat mempertimbangkan pendapat orang lain serta mampu mengungkapkan pendapatnya sendiri. Oleh karena itu pembelajaran di sekolah sebaiknya melatih peserta didik untuk menggali kemampuan dan keterampilan dalam mencari, mengolah, dan menilai berbagai informasi secara kritis. Model pembelajaran yang digunakan guru seharusnya dapat membantu proses analisis peserta didik. Salah satu model pembelajaran tersebut adalah model pembelajaran Problem Based Learning. Dengan menerapkan model pembelajaran Problem Based Learning pada pembelajaran Matematika diharapkan peserta didik akan mampu menggunakan dan mengembangkan kemampuan berpikir kritis untuk menyelesaikan masalah dengan menggunakan berbagai strategi penyelesaian. Oleh karena itu, penelitian ini bertujuan untuk mendeskripsikan kemampuan berpikir kritis peserta didik dalam menyelesaikan masalah matematika melalui model pembelajaran Problem Based Learning.

Penelitian ini merupakan penelitian deskriptif kuantitatif. Penelitian ini dilaksanakan di SMP Negeri 1 Glagah Lamongan pada kelas VII-A sebanyak 15 peserta didik tahun akademik 2017/2018. Metode pengumpulan data adalah metode tes. Metode tes digunakan untuk mendapatkan data kemampuan berpikir kritis peserta didik dalam menyelesaikan masalah matematika. Instrumen yang digunakan dalam penelitian ini adalah tes kemampuan berpikir kritis.

Hasil Penelitian menunjukkan bahwa rata-rata kemampuan berpikir kritis peserta didik berkategori tinggi, dengan rincian 9 peserta didik atau 60\% memiliki kemampuan berpikir kritis sangat tinggi, 3 peserta didik atau 20\% memiliki kemampuan berpikir kritis tinggi, 2 peserta didik atau 14\% memiliki kemampuan berpikir kritis sedang, sedangkan 1 peserta didik atau $6 \%$ memiliki kemampuan berpikir kritis rendah
\end{abstract}

Kata kunci: kemampuan berpikir kritis, pemecahan masalah, Problem Based Learning 


\begin{abstract}
Critical thinking ability can train the students to make decisions from various points of view carefully, thoroughly, and logically, to consider the opinions of others and able to express their own opinions. Therefore, learning in school should train them to explore the skills in searching, processing, and assessing the various of information critically. Learning model which is used by the teacher should be able to assist the processof analysis of students. One of them is Problem Based Learning which is to engage the students to use and develop critical thinking skill to solve problems by using various strategies of completion in learning mathematics. Therefore, this study aims to describe the ability of critical thinking of students in solving mathematical problems through Probem Based Learning.

This research is quantitative descriptive that was conducted at VII A class in SMP Negeri 1 Glagah Lamongan as many as 15students in academic year 2017/2018. Data collection method is test method that is used to get the data of critical thinking ability of students in solving math problem. Instrumen which is used in this research is critical thinking ability test.

The results of this study show that the average of students thinking ability is in high category, in which 9 students or 60\% have very high critical thinking skill, 3 students or 20\% have high critical thinking skill, 2 students or 14\% have medium critical thinking skill, and 1 student or $6 \%$ have low critical thinking skill.
\end{abstract}

Keywords: critical thinking skills, problem solving, Problem Based Learning

\section{PENDAHULUAN}

Salah satu tujuan mata pelajaran matematika yang dimuat dalam Standar Isi Mata Pelajaran Matematika SMP pada Permendiknas Nomor 22 Tahun 2006 adalah agar peserta didik mampu memecahkan masalah matematika yang meliputi kemampuan memahami masalah, merancang model matematika, menyelesaikan model dan menafsirkan solusi yang diperoleh (Depdiknas, 2006). Kemampuan pemecahan masalah tersebut perlu dikuasai peserta didik guna mendorong mereka menjadi seorang pemecah masalah yang baik, yang mampu menghadapi masalah dalam kehidupan sehari-hari maupun dalam dunia kerja.
Menurut Wono (Napitupulu, 2012), pembelajaran matematika di Indonesia masih menekankan menghafal rumus dan menghitung. Selain itu, belajar matematika yang seharusnya membantu peserta didik mengembangkan logika, reasoning, dan beragumentasi tidak pernah dikembangkan dalam pendidikan matematika di sekolah. Menurut Endahwari (2010) salah satu faktor yang menyebabkan matematika terasa sulit bagi peserta didik adalah keabstrakan matematika, sehingga peserta didik sulit untuk membayangkan apa yang sedang mereka pelajari. Pembelajaran matematika saat ini masih cenderung menggunakan pendekatan konvensional, dimana pendekatan menerangkan dengan ceramah 
lebih ditekankan daripada penguasaan konsep matematika. Akibatnya ketrampilan berpikir tinggi seperti kemampuan berpikir kritis matematik dalam memecahkan masalah kurang berkembang.

Pendidikan matematika memiliki peran yang sangat penting karena matematika ilmu dasar yang digunakan secara luas dalam berbagai bidang kehidupan. Permen 22 Tahun 2006 (Standar Isi) menyatakan bahwa pelajaran matematika diberikan kepada semua peserta didik untuk membekali mereka dengan kemampuan berpikir logis, analitis, sistematis, kritis, kreatif dan kemampuan bekerjasama. Oleh karena itu, kemampuan berpikir kritis merupakan salah satu prioritas dalam pembelajaran matematika.

Menurut Krulik dan Rudnick (NCTM, 2000) mengemukakan bahwa yang termasuk berpikir kritis dalam matematika adalah kemampuan berpikir yang meliputi unsur menguji, mempertanyakan, menghubungkan, mengevaluasi semua aspek yang ada dalam suatu situasi ataupun suatu masalah matematika. Rosyada (2004: 170), kemampuan berpikir kritis tidak lain adalah kemampuan peserta didik dalam mengumpulkan berbagai informasi lalu membuat kesimpulan evaluatif dari berbagai informasi tersebut. Kemampuan berpikir kritis melatih peserta didik membuat keputusan dari berbagai sudut pandang secara cermat, teliti, dan logis. Dengan kemampuan berpikir kritis peserta didik dapat mempertimbangkan pendapat orang lain serta mampu mengungkapkan pendapatnya sendiri. Oleh karena itu, pembelajaran di sekolah sebaiknya melatih peserta didik untuk menggali kemampuan dan keterampilan dalam mencari, mengolah, dan menilai berbagai informasi secara kritis.

Berpikir kritis adalah berpikir rasional dalam menilai sesuatu. Sebelum mengambil suatu keputusan atau melakukan suatu tindakan, maka dilakukan pengumpulkan informasi sebanyak mungkin tentang sesuatu tersebut. Pada dasarnya kemampuan berpikir kritis erat kaitannya dengan proses berpikir kritis dan indikatorindikatornya. Indikator berpikir kritis dapat dilihat dari karakteristiknya sehingga dengan memiliki karakteristik tersebut seseorang dapat dikatakan telah memiliki kemampuan berpikir kritis. Facione (dalam Filsaime, 2008) mengungkapkan enam kecakapan berpikir kritis utama yang terlibat di dalam proses berpikir kritis, yaitu:

1) Interpretasi adalah memahami masalah yang ditunjukkan dengan menulis diketahui maupun yang ditanyakan soal 
dengan tepat; 2) Analisis adalah mengidentifikasi hubungan-hubungan antara pernyataan- pernyataan, pertanyaaan-pertanyaan, dan konsepkonsep yang diberikan dalam soal yang menunjukkan dengan membuat model matematika dengan tepat dan memberi penjelasan dengan tepat; 3) Evaluasi adalah menggunakan strategi yang tepat dalam menyelesaikan soal, lengkap dan benar dalam melakukan perhitungan; 4) Inferensi adalah mengidentifikasi dan memperoleh unsur-unsur yang diperlukan untuk membuat kesimpulan-kesimpulan yang masuk akal, membuat dugaan-dugaan dan hipotesis, mempertimbangkan informasi yang relevan dan menyimpulkan konsekuensikonsekuensi dari data; 5) Eksplanasi adalah menyatakan hasil-hasil, menjustifikasi prosedur-prosedur dan mempersentasikan hasil argumenargumen; 6) Regulasi diri adalah pengujian diri dari koreksi diri. Penelitian ini menggunakan 4 kecakapan utama berpikir kritis menurut Facione sebagai indikator kemampuan berpikir kritis. Hal ini karena untuk eksplanasi dan regulasi diri dalam indikator kemampuan berpikir kritis tidak termasuk dalam jenjang SMP/MTS (Karim, 1996: 92104). Dalam pembelajaran matematika pemecahan masalah merupakan aktivitas yang penting. Bahkan Holmes (dalam NCTM, 1980), menyatakan bahwa pemecahan masalah adalah "jantung" dari matematika (heart of mathematics). Karena dalam pemecahan masalah matematika memerlukan pengetahuan materi matematika, pengetahuan tentang strategi pemecahan masalah, pemantauan diri yang efektif, dan suatu sikap produktif untuk menyikapi dan menyelesaikan masalah (Dewi, 2009: 25). Demikian juga Suryadi (dalam Suherman dkk, 2001) menyebutkan bahwa pemecahan masalah matematika merupakan salah satu kegiatan matematika yang dianggap penting baik oleh guru maupun peserta didik di semua tingkat, mulai dari SD sampai SMA bahkan perguruan tinggi. Tanpa adanya kemampuan untuk memecahkan masalah maka kegunaan dan kekuatan ide-ide matematika, pengetahuan, dan keterampilan sangat terbatas.

Pemilihan model pembelajaran yang tepat juga akan memperjelas konsepkonsep yang diberikan sehingga peserta didik selalu antusias berpikir dan berperan aktif (Suryanti, 2017). Tujuan pembelajaran akan memperjelas proses belajar mengajar dalam arti situasi dan kondisi yang harus diperbuat dalam proses belajar mengajar. 
Model pembelajaran yang digunakan guru seharusnya dapat membantu proses analisis peserta didik. Salah satu model pembelajaran tersebut adalah model pembelajaran Problem Based Learning. Menurut Arends (2008: 41), PBL merupakan model pembelajaran yang memberikan berbagai situasi bermasalah yang autentik dan bermakna kepada peserta didik, yang dapat berfungsi sebagai batu loncatan untuk investigasi dan penyelidikan. PBL membantu peserta didik untuk mengembangkan keterampilan berpikir kritis dan keterampilan menyelesaikan masalah. Model pembelajaran Problem Based Learning lebih menekankan pada usaha penyelesaian masalah melalui kegiatan penyelidikan. Kegiatan penyelidikan termasuk ciri-ciri dari kemampuan berpikir kritis. Diharapkan model pembelajaran Problem Based Learning lebih baik untuk meningkatkan keaktifan peserta didik jika dibandingkan dengan model konvensional. Keefektifan model ini adalah peserta didik lebih aktif dalam berpikir dan memahami materi secara berkelompok dengan melakukan investigasi dan inkuiri terhadap permasalahan yang nyata di sekitarnya sehingga mereka mendapatkan kesan yang mendalam dan lebih bermakna tentang apa yang mereka pelajari. Dengan menerapkan model pembelajaran Problem Based Learning pada pembelajaran Matematika diharapkan peserta didik akan mampu menggunakan dan mengembangkan kemampuan berpikir kritis untuk menyelesaikan masalah dengan menggunakan berbagai strategi penyelesaian.

$$
\text { Berdasarkan latar belakang }
$$
masalah yang telah dikemukakan, maka rumusan masalah dari penelitian ini adalah bagaimana kemampuan berpikir kritis peserta didik dalam menyelesaikan masalah matematika melalui model pembelajaran Problem Based Learning di kelas VII SMP Negeri 1 Glagah Lamongan?

Jadi, tujuan dalam penelitian ini adalah untuk mendiskripsikan kemampuan berpikir kritis peserta didik dalam menyelesaikan masalah matematika melalui model pembelajaran Problem Based Learning di kelas VII SMP Negeri 1 Glagah Lamongan.

\section{METODE PENELITIAN}

Jenis penelitian ini adalah penelitian deskriptif kuantitatif. Penelitian ini dilaksanakan di SMP Negeri 1 Glagah Lamongan. Subjek penelitian ini adalah peserta didik kelas VII-A SMP Negeri 1 Glagah Lamongan tahun pelajaran 
2017/2018 yang berjumlah 15 peserta didik. Materi yang digunakan dalam penelitian ini adalah materi himpunan di kelas VII SMP semester ganjil tahun pelajaran 2017/2018.

Metode yang digunakan adalah metode tes. Instrumen yang digunakan dalam penelitian ini adalah lembar tes kemampuan berpikir kritis. Instrumen yang digunakan dalam penelitian ini terlebih dahulu divalidasi oleh validator. Metode analisis data

pada penelitian ini digunakan untuk mengolah data yang telah dikumpulkan oleh peneliti. Data yang diperoleh merupakan data nilai hasil tes kemampuan berpikir kritis. Kemudian untuk menentukan persentase masingmasing indikator kemampuan berpikir kritis pada tiap peserta didik dengan rumus:

$$
A_{i}=\frac{\sum_{n=1}^{m=4} I_{n s}}{\text { Skormaksimal }} \times 100 \%
$$

Keterangan:

$A_{i}=$ Persentase kemampuan berpikir kritis indikator ke-i

$I_{n s}=$ Indikator kemampuan Berpikir kritis ke-n, soal ke-s;

$\mathrm{n}=1,2,3,4 ; \mathrm{s}=1,2,3$

Tahap terakhir menentukan persentase seluruh kemampuan berpikir kritis peserta didik pada tiap indikator dengan menjumlahkan seluruh masing- masing indikator kemampuan berpikir kritis. Kemudian, menentukan rata-rata kemampuan berpikir kritis peserta didik pada tiap indikator dalam satu kelompok dengan rumus:

$$
\bar{x}=\frac{\sum_{s=1}^{n} I_{k s}}{n} \times 100 \%
$$

Keterangan :

$I_{k}=$ Persentase kemampuan berpikir kritis pada tiap indikator

$a=$ Banyaknya indikator

$S=$ peserta didik ke-n

$n=$ Banyaknya pada tiap kelompok

Selanjutnya, menentukan rata-rata kemampuan berpikir kritis untuk setiap peserta didik dengan rumus:

$$
\bar{x}=\frac{M}{a}
$$

Keterangan :

$M=$ Banyaknya persentase hasil penjumlahan seluruh indikator di setiap peserta didik

$a=$ Banyaknya indikator

Kemudian mengkategorikan kemampuan berpikir kritis setiap peserta didik di setiap indikator dan masingmasing indikator kemampuan berpikir kritis dengan melihat kategori penilaian sebagai berikut:

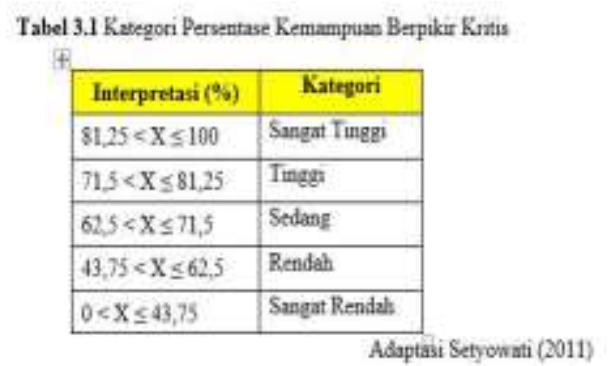


Prosedur penelitian yang digunakan dalam penelitian ini dibagi menjadi tiga tahap, yaitu tahap persiapan, tahap pelaksanaan, dan tahap analisis data.

\section{HASIL DAN ANALISIS DATA}

Berdasarkan hasil kegiatan pembelajaran yang dilakukan selama tiga pertemuan dengan menggunakan tahapan-tahapan model Problem Based Learning, pembahasan dari pembelajaran pertama ini adalah sebagai berikut:

Tahap pertama yaitu mengorientasikan peserta didik pada masalah matematika. Pada tahap ini guru mengorientasikan peserta didik pada masalah matematika yang berkaitan dengan konsep himpunan dan diagram venn. Guru memberikan contoh himpunan, contoh bukan himpunan serta syarat suatu himpunan untuk memahami konsep himpunan. Kemudian memberikan contoh penyajian himpunan dengan 3 cara, yaitu pertama menuliskan anggotanya, kedua syarat menuliskan anggotanya dan ketiga notasi pembentuk himpunan. Kemudian guru memberikan contoh himpunan semesta. Kemudian guru memberikan pertanyaan kepada peserta didik tentang konsep himpunan dan diagram venn, salah satunya seperti pada saat guru memberikan pertanyaan "Apakah yang dimaksud dengan suatu himpunan, himpunan semesta dan berikan contohnya?". Peserta didik menjawab berbagai pertanyaan yang di sajikan oleh guru secara bergantian.

Tahap kedua yaitu mengorganisasikan peserta didik untuk belajar. Pada tahap ini, guru mengorganisir peserta didik dalam kelompok. Guru meminta peserta didik untuk berhitung satu, dua dan tiga secara bergantian dimana peserta didik yang berhitung satu, dua, dan tiga menjadi satu kelompok. Kemudian guru meminta peserta didik berkumpul pada kelompoknya masing-masing. Pembentukan kelompok terdiri dari 5 kelompok yang masing-masing kelompok terdapat 3 peserta didik.

Tahap ketiga yaitu membimbing pengalaman individual/kelompok. Pada tahap ini, guru memberikan Lembar Kerja Kelompok 1 (LKK 1). Kemudian guru meminta peserta didik untuk mendiskusikan dengan teman sekelompoknya mengenai masalah matematika yang terdapat pada LKK 1. Guru mempersilahkan peserta didik untuk bertanya apabila ada soal dalam LKK 1 yang belum bisa dipahami. Guru mengawasi dan mengarahkan jalannya 
diskusi pada masing-masing kelompok secara bergantian.

Tahap keempat yaitu mengembangkan dan menyajikan hasil karya. Pada tahap ini, guru meminta peserta didik menyiapkan laporan hasil kerja kelompok. Kemudian guru meminta salah satu perwakilan kelompok untuk mempresentasikan hasil diskusinya di depan kelas. Guru menunjuk kelompok dengan cara menyebutkan kelompok yang selesai terlebih dahulu. Kelompok yang selesai terlebih dahulu adalah kelompok 2 . Setelah kelompok yang ditunjuk mempresentasikan hasil diskusi kelompok, guru memberikan kesempatan kepada peserta didik dari kelompok lain untuk memberikan tanggapan kepada kelompok penyaji. Kemudian kelompok 1 memberikan tanggapan bahwa jawaban pada point D salah dan kelompok 1 memberikan jawaban yang berbeda.

Tahapan yang terakhir adalah tahap menganalisis dan mengevaluasi proses pemecahan masalah. Setelah kelompok tersebut mempresentasikan hasil diskusinya, guru membantu peserta didik untuk melakukan evaluasi terhadap proses dan hasil presentasi yang mereka lakukan. Guru memberi umpan balik dan mengarahkan peserta didik pada kesimpulan yang benar.
Setelah melakukan tes kemampuan berpikir kritis kepada peserta didik kelas VII-A SMP Negeri 1 Glagah Lamongan, hasil tes tersebut diperiksa dan diberi skor pada tiap indikator kemampuan berpikir kritis dari tiap soal. Kemudian skor per indikator dari setiap soal dijumlahkan dan menentukan persentase per indikator kemampuan berpikir kritis. Selanjutnya, menentukan persentase seluruh kemampuan berpikir kritis pada tiap indikator dengan menjumlahkan per indikator kemampuan berpikir kritis dan menentukan rata-rata kemampuan berpikir kritis peserta didik pada tiap indikator.Selanjutnya, mengkategorikan per indikator kemampuan berpikir kritis. Data selengkapnya dapat dilihat pada hasil analisis berikut: 
1. Analisis Kemampuan Berpikir

Kritis Peserta Didik Berdasarkan Indikator

\begin{tabular}{|c|c|c|c|}
\hline \multicolumn{5}{|c|}{ Persentase Per Indikator Kemampuan } \\
Berpikir Kritis \\
\hline 1 & 2 & 3 & 4 \\
\hline 100 & 88 & 88 & 83 \\
\hline 100 & 88 & 66 & 83 \\
\hline 100 & 88 & 88 & 83 \\
\hline 100 & 77 & 77 & 83 \\
\hline 100 & 77 & 55 & 66 \\
\hline 77 & 55 & 55 & 83 \\
\hline 100 & 66 & 77 & 66 \\
\hline 100 & 77 & 66 & 83 \\
\hline 100 & 88 & 77 & 83 \\
\hline 66 & 66 & 66 & 66 \\
\hline 100 & 66 & 66 & 83 \\
\hline 100 & 77 & 77 & 83 \\
\hline 100 & 88 & 77 & 83 \\
\hline 100 & 66 & 77 & 83 \\
\hline 66 & 44 & 44 & 66 \\
\hline 1409 & 1111 & 1056 & 1177 \\
\hline 93,93 & 74,06 & 70,4 & 78,46 \\
\hline Sangat & Tinggi & Sedang & Tinggi \\
Tinggi & \multicolumn{4}{|c|}{} \\
\hline \multicolumn{4}{|c|}{79,21} \\
\hline Tinggi \\
\hline
\end{tabular}

Berdasarkan hasil analisis bahwa pada kolom persentase per indikator kemampuan berpikir kritis peserta didik pada indikator pertama yaitu menginterpretasi nilai persentase secara keseluruhan berjumlah 1409 dengan rata-rata persentase 93,93 termasuk dalam kategori sangat tinggi.

Pada indikator kedua yaitu menganalisis nilai persentase secara keseluruhan berjumlah 1111 dengan rata-rata persentase 74,06 termasuk dalam kategori tinggi. Pada indikator ketiga yaitu mengevaluasi nilai persentase secara keseluruhan berjumlah 1056 dengan rata-rata persentase 70,4 termasuk dalam kategori sedang. Pada indikator keempat yaitu menginferensi persentase secara keseluruhan berjumlah 1177 dengan rata-rata persentase 78,46 termasuk dalam kategori tinggi.

Kemudian setelah mengetahui kategori persentase per indikator dapat ditentukan kategori persentase indikator secara keseluruhan. Berdasarkan hasil analisis bahwa pada kolom persentase masing-masing indikator kemampuan berpikir kritis peserta didik. Jumlah persentase per indikator dijumlahkan kemudian dibagi banyaknya indikator dan hasilnya adalah 1188,25. Selanjutnya, dibagi banyaknya peserta didik dan dikali $100 \%$. Setelah itu bisa diketahui hasil rata-rata persentase indikator secara keseluruhan adalah 79,21. Kemudian ratarata persentase indikator secara keseluruhan dikategorikan sesuai dengan petunjuk kategori persentase kemampuan berpikir kritis. Jadi, persentase indikator secara keseluruhan termasuk dalam kategori tinggi. 
2. Analisis Kemampuan Berpikir Kritis Peserta Didik Berdasarkan Penilaian Individu

\begin{tabular}{|c|c|c|c|c|c|}
\hline \multicolumn{3}{|c|}{$\begin{array}{c}\text { Persentase Per } \\
\text { Indikator }\end{array}$} & \multicolumn{2}{|c|}{ Kemampuan } \\
Berpikir Kritis & RATA- & KATEGORI \\
\hline 1 & 2 & 3 & 4 & & \\
\hline 100 & 88 & 88 & 83 & 89,75 & $\begin{array}{c}\text { Sangat } \\
\text { Tinggi }\end{array}$ \\
\hline 100 & 88 & 66 & 83 & 84,25 & $\begin{array}{c}\text { Sangat } \\
\text { Tinggi }\end{array}$ \\
\hline 100 & 88 & 88 & 83 & 89,75 & $\begin{array}{c}\text { Sangat } \\
\text { Tinggi }\end{array}$ \\
\hline 100 & 77 & 77 & 83 & 84,25 & $\begin{array}{c}\text { Sangat } \\
\text { Tinggi }\end{array}$ \\
\hline 100 & 77 & 55 & 66 & 74,5 & Tinggi \\
\hline 77 & 55 & 55 & 83 & 67,5 & Sedang \\
\hline 100 & 66 & 77 & 66 & & Tinggi \\
\hline 100 & 77 & 66 & 83 & 81,5 & $\begin{array}{c}\text { Sangat } \\
\text { Tinggi }\end{array}$ \\
\hline 100 & 88 & 77 & 83 & 87 & $\begin{array}{c}\text { Sangat } \\
\text { Tinggi }\end{array}$ \\
\hline 66 & 66 & 66 & 66 & 66 & Sedang \\
\hline 100 & 66 & 66 & 83 & 78,75 & Tinggi \\
\hline 100 & 77 & 77 & 83 & 84,25 & $\begin{array}{c}\text { Sangat } \\
\text { Tinggi }\end{array}$ \\
\hline 100 & 88 & 77 & 83 & 87 & $\begin{array}{c}\text { Sangat } \\
\text { Tinggi }\end{array}$ \\
\hline 100 & 66 & 77 & 83 & 81,5 & $\begin{array}{c}\text { Sangat } \\
\text { Tinggi }\end{array}$ \\
\hline 66 & 44 & 44 & 66 & 55 & Rendah \\
\hline & Berdasarkan & hasil & analisis \\
\hline
\end{tabular}

bahwa untuk mengetahui kemampuan berpikir kritis peserta didik berdasarkan penilaian individu. Pada baris setiap peserta didik dapat dilihat nilai persentase per indikator kemampuan berpikir kritis. Kemudian nilai persentase per indikator kemampuan berpikir kritis setiap peserta didik dijumlah dan dibagi banyaknya indikator untuk menentukan rata-rata persentase per indikator kemampuan berpikir kritis peserta didik. Kemudian rata-rata persentase per indikator kemampuan berpikir kritis setiap peserta didik dikategorikan sesuai dengan petunjuk kategori persentase kemampuan berpikir kritis. Kemudian setelah mengetahui kategori setiap peserta didik, didapat data kemampuan berpikir kritis setiap peserta didik seperti pada hasil kemampuan berpikir kritis berikut:

\begin{tabular}{|c|c|c|c|}
\hline No & Kriteria Penilaian & Banyaknya Peserta Didik & Perseatase (\%) \\
\hline 1 & Saugat Timggi & 9 & 60 \\
\hline 2 & Tingei & 3 & 20 \\
\hline 3 & Setane & 2 & 14 \\
\hline 4 & Reniah & 1 & 6 \\
\hline 5 & Sangat Renbah & - & - \\
\hline \multicolumn{2}{|r|}{ Jumleh } & 15 & 100 \\
\hline
\end{tabular}

Dari analisis tes kemampuan berpikir kritis peserta didik di kelas VII A di SMP Negeri 1 Glagah Lamongan pada hasil kemampuan berpikir kritis, dapat dijabarkan bahwa 9 peserta didik atau $60 \%$ memiliki kemampuan berpikir kritis sangat tinggi, 3 peserta didik atau 20\% memiliki kemampuan berpikir kritis tinggi, 2 peserta didik atau 14\% memiliki kemampuan berpikir kritis sedang, sedangkan 1 peserta didik atau $6 \%$ memiliki kemampuan berpikir kritis rendah.

Berdasarkan hasil analisis untuk mengetahui kategori indikator kemampuan berpikir kritis setiap peserta didik secara keseluruhan yaitu pada baris setiap peserta didik dapat dilihat nilai 
persentase per indikator kemampuan berpikir kritis. Kemudian nilai persentase per indikator kemampuan berpikir kritis dijumlah dan dibagi banyaknya indikator untuk menentukan rata-rata persentase per indikator kemampuan berpikir kritis setiap peserta didik. Kemudian rata-rata persentase per indikator kemampuan berpikir kritis setiap peserta didik dijumlah secara keseluruhan dan hasilnya adalah 1188,25 dengan ratarata 79,21 . Kemudian rata-rata tersebut dikategorikan sesuai dengan petunjuk kategori persentase kemampuan berpikir kritis. Jadi, rata-rata persentase kemampuan berpikir kritis di setiap peserta didik termasuk dalam kategori tinggi.

\section{PEMBAHASAN}

Berdasarkan hasil analisis, dapat dijelaskan bahwa persentase kemampuan berpikir kritis peserta didik pada indikator menginterpretasi termasuk dalam kategori sangat tinggi, menganalisis dan menginferensi termasuk dalam kategori tinggi, serta mengevaluasi termasuk dalam kategori sedang. Berikut ini deskripsi hasil persentase kemampuan berpikir kritis peserta didik masing-masing indikator dalam menyelesaikan masalah matematika melalui model Problem Based Learning.

Indikator 1: Interpretasi

Berdasarkan hasil analisis, sangat tingginya kemampuan berpikir kritis peserta didik pada indikator interpretasi dikarenakan pada kegiatan pembelajaran peneliti mendorong peserta didik melalui Lembar Kerja Kelompok untuk terbiasa menuliskan apa yang diketahui dan apa yang ditanyakan sehingga memudahkan peserta didik dalam memahami soal. Pada tahap pertama yaitu orientasi peserta didik pada masalah matematika. Pada tahap ini guru memberi beberapa contoh mengenai materi himpunan dan memberikan contoh soal. Kemudian pada tahap kedua mengorganisasi peserta didik dimana membagi peserta didik menjadi beberapa kelompok. Pada tahap ini guru membuat beberapa kelompok untuk mendiskusikan masalah matematika pada lembar kerja kelompok yang diberikan oleh guru. Selanjutnya, pada tahap ketiga yaitu membimbing penyelidikan individu maupun kelompok dimana guru mendorong peserta didik untuk mendiskusikan dengan teman kelompoknya. Pada tahap ini guru meminta peserta didik untuk berdiskusi dengan teman kelompoknya mengenai masalah matematika yang diberikan oleh guru. Kemudian peserta didik mengumpulkan informasi yang 
dibutuhkan seperti merumuskan atau menuliskan apa yang diketahui dan apa yang ditanyakan sehingga memudahkan peserta didik dalam memahami soal. Dengan demikian hal tersebut menunjukkan bahwa dengan melaksanakan kegiatan pembelajaran menggunakan model Problem Based Learning mulai tahap pertama, kedua dan ketiga mampu membentuk kemampuan berpikir kritis peserta didik dalam menginterpretasi suatu masalah.

Indikator 2: Menganalisis

Pada pembelajaran dengan model Problem Based Learning, pada tahap keempat peneliti membimbing peserta didik menyelesaikan Lembar Kerja Kelompok dan membantu peserta didik mengembangkan dan menyajikan hasil penyelesaian pemecahan dan pengajuan masalah. Namun pada saat tes kemampuan berpikir kritis meskipun hampir seluruh peserta didik membuat model matematika dengan tepat ternyata masih ada beberapa peserta didik yang hanya membuat model matematika tanpa memberi penjelasan.

Indikator 3: Mengevaluasi

Dalam menyelesaikan tes kemampuan berpikir kritis, strategi yang digunakan hampir seluruh peserta didik sudah sangat jelas dan benar mau dibawa kemana arah penyelesaiannya. Namun hal yang luput dari perhatian hampir seluruh peserta didik adalah ketidak telitian mereka dalam proses menghitung, sehingga tidak sedikit dari mereka yang benar dalam melakukan strategi penyelesaian namun melakukan kesalahan dalam perhitungan. Seperti pada tahap kelima yaitu menganalisis dan mengevaluasi proses data hasil pemecahan masalah dimana peserta didik melakukan evaluasi terhadap proses dan hasil penyelidikan yang dilakukan. Oleh karena itu, dapat disimpulkan bahwa dengan melaksanakan kegiatan pembelajaran menggunakan model Problem Based Learning mampu membentuk kemampuan berpikir kritis peserta didik dalam mengevaluasi suatu masalah.

\section{Indikator 4: Menginferensi}

Dalam hal ini hampir seluruh peserta didik sudah dapat membuat kesimpulan yang sesuai dengan konteks soal. Meskipun sudah dapat membuat kesimpulan sesuai dengan konteks soal, ada sebagian peserta didik yang tidak tepat dalam membuat kesimpulan. Salah satu penyebabnya adalah pada saat menyelesaikan masalah (evaluasi) peserta didik melakukan kesalahan dalam 
perhitungan sehingga kesimpulan yang mereka dapatkan menjadi tidak tepat.

\section{SIMPULAN}

Berdasarkan hasil analisis data penelitian, maka diperoleh kesimpulan bahwa rata-rata kemampuan berpikir kritis peserta didik kelas VII-A di SMP Negeri 1 Glagah Lamongan dalam menyelesaikan masalah matematika setelah menggunakan model Problem Based Learning berkategori tinggi dengan rincian 9 peserta didik atau $60 \%$ memiliki kemampuan berpikir kritis sangat tinggi, 3 peserta didik atau 20\% memiliki kemampuan berpikir kritis tinggi, 2 peserta didik atau $14 \%$ memiliki kemampuan berpikir kritis sedang, sedangkan 1 peserta didik atau 6\% memiliki kemampuan berpikir kritis rendah.

\section{DAFTAR PUSTAKA}

Arends, Richard. 2008. Learning

to Teach. Penerjemah: Helly Prajitno \& Sri Mulyani. New York: McGraw Hill Company. Depdiknas. 2006. Standar Isi Mata Pelajaran Matematika SMP/MTs. Jakarta:Depdiknas Endahwari, Dyah Sapta. 2010. Eksperimentasi Pendekatan Pemecahan Masalah Polya dalam Metode Diskusi pada
Soal Cerita Sistem Persamaan Linier Dua Variabel Ditinjau dari Kreatif Belajar Peserta didik Kelas VIII Semester Gasal SMP Negeri 10 Surakarta Tahun Pelajaran 2009/2010, Skripsi:FKIP UNS

Filsaime, Dennis K. 2008. Menguak Rahasia Berpikir Kritis dan Kreatif. Diterjemahkan oleh Sunarni ME. Jakarta: Prestasi Pustaka Publisher

Karim. Normaya., (2015), Kemampuan Brpikir Kritis Siswa Dalam Pembelajaran Matematika dengan mengunakan Model Jucama, Jurnal Pendidikan Matematika, Vol 3, No 1, Hal 92-104.

Napitupulu, Ester Lince. 2012. Prestasi Sains dan Matematika Indonesia Menurun, Kompas (14 Desember 2012)

NCTM. 1980. Problem

Solving in School

Mathematics. Yearbook:NCTM Inc.

NCTM. 2000. Principles and Standards for School Mathematics. USA: The National Council of Teachers Mathematics, Inc.

Rosyada, Dede. 2004. Paradigma Pendidikan Demokratis Sebuah Modal Masyarakat dalam Penyelenggaraan Pendidikan. Jakarta: Prenada Media. 
Suryanti, S., Khikmiyah, F. A. T. I. M.

A. T. U. L., Zawawi, I., \&

Fauziyah, S. (2017).

PENINGKATAN

PENGUASAAN KONSEP

MATRIKS MELALUI

MODEL PEMBELAJARAN

KOOPERATIF TIPE TWO

STAY TWO STRAY (TSTS).

DIDAKTIKA: Jurnal Pemikiran

Pendidikan, 21(1), 14-27. 